Article

\title{
Applying a Graphical Method in Evaluation of Empirical Methods for Estimating Time of Concentration in an Arid Region
}

\author{
Ali Zahraei ${ }^{1}$, Ramin Baghbani ${ }^{2, *}$ and Anna Linhoss ${ }^{3}$ \\ 1 Department of Irrigation and Drainage Engineering, College of Abureyhan, University of Tehran, \\ Tehran 3391653755, Iran; alizahraei110@gmail.com \\ 2 Department of Agriculture and Biological Engineering, Mississippi State University, \\ Starkville, MS 39762, USA \\ 3 Department of Biosystems Engineering, Auburn University, Auburn, AL 36849, USA; ac10089@auburn.edu \\ * Correspondence: rb2132@msstate.edu; Tel.: +1-315-909-1414
}

Citation: Zahraei, A.; Baghbani, R.; Linhoss, A. Applying a Graphical Method in Evaluation of Empirical Methods for Estimating Time of Concentration in an Arid Region. Water 2021, 13, 2624. https:// doi.org/10.3390/w13192624

Academic Editors: Sajjad Ahmad and Silvia Kohnová

Received: 2 June 2021

Accepted: 18 September 2021

Published: 24 September 2021

Publisher's Note: MDPI stays neutral with regard to jurisdictional claims in published maps and institutional affiliations.

Copyright: () 2021 by the authors. Licensee MDPI, Basel, Switzerland. This article is an open access article distributed under the terms and conditions of the Creative Commons Attribution (CC BY) license (https:// creativecommons.org/licenses/by/ $4.0 /)$.

\begin{abstract}
At gauged watersheds, the time of concentration can be estimated using rainfall-runoff data; however, at ungauged watersheds, empirical methods are used instead. Large errors in the application of empirical methods may cause inaccurate modeling of floods and unreliable structure design. In this paper, methods for calculating the time of concentration (Tc) were compared to identify the best equation for estimating Tc in ungauged watersheds of an arid region. The graphical method, based on measured data, was compared to 15 empirical methods to determine which empirical method returned the best results. The graphical method was applied to 33 rainfall-runoff events in four rural sub-watersheds located in the central parts of Hormozgan province, Iran. A rankingbased procedure was used to select the best performing empirical methods. To minimize bias and improve accuracy, the best performing empirical methods were modified by adjusting their formulas. According to the study, three empirical methods: (1) Williams, (2) Pilgrim and Mac Dermott, and (3) Arizona DOT, performed the best in the study areas. The results also showed that the modified Williams and Arizona DOT's formulas were able to estimate the time of concentration in ungauged watersheds with an error lower than $1 \%$.
\end{abstract}

Keywords: time of concentration; hydrograph; hydrology; graphical method; flood; arid

\section{Introduction}

Arid and semiarid areas, which cover a wide part of the world, are influenced by extreme flooding related to torrential rainfall events [1-3]. One important parameter in the development of a flood hydrograph in ungauged watersheds is the time of concentration (Tc). Tc reflects the speed of waterflow in a watershed in response to rainfall events, proving effective in the implementation of stormwater management and flood warning systems [4]. Bondelid et al. [5] showed that $75 \%$ of the error in estimating peak discharge could be a result of errors in the estimation of the time of concentration. Due to the lack of sufficient data in arid regions, estimating the time of concentration is a major challenge [6,7].

Numerous studies have been conducted to study the time of concentration in gauged and ungauged watersheds. Empirical methods are widely used to determine the time of concentration in ungauged watersheds. Each empirical method is developed in a particular region with specific physical and climatic characteristics. Thus, when these methods are used for other areas of the world, their accuracy needs to be evaluated, and, if necessary, their equations should be modified.

There are several studies describing the evaluation and modification of empirical methods for determining Tc. Efstratiadis et al. [8] applied four widely used empirical methods in Cyprus, including Kirpich, Giandotti, SCS (Soil Conservation Service), and Passini 
methods, to estimate Tc. They used the observed and estimated peak discharge to evaluate empirical methods and, in doing so, found that the Giandotti was the most appropriate method in estimating Tc in Cyprus. Salimi et al. [9] used a similar evaluation procedure for assessing seven empirical methods in humid regions of northern Iran; this study showed the peak flow value obtained by the Bransby-Williams method was most consistent with the observed peak data values. González-Álvarez et al. [10] assessed 10 empirical methods for 15 urban ungauged watersheds using the velocity method (as a reference method); as a result, it showed that none of the equations were reliable for estimating Tc in all watersheds, as only four methods had very good performances in eight studied watersheds. They selected Kirpich and FFA methods, which show the best correlation between the estimated and reference value of Tc, for modification. To minimize the bias of estimation, they adjusted the equations. Sharifi and Hosseini [11] proposed a methodology for identifying the best Tc empirical equation. They considered Tc calculated by the velocity method (NRCS, 1986) as a reference method for comparison. Then, they modified empirical equations using correction factors, which were obtained from the inverse of the linear regression slope between estimated values of Tc by empirical equations and the reference value. To select the best method, they evaluated each method using several statistical measures and the ranking-based strategy. They applied this methodology to 72 temperate watersheds and sub-watersheds in the northeast of Iran; doing so, they found the California, Kirpich, and Arizona DOT (Departement Of Transpoatation) methods with modified equations displayed the best performance. Perdikaris et al. [12] evaluated eight empirical methods in Credit River watershed, Ontario, Canada using the velocity method as a reference method. They applied the ranking of each method, based on statistical and goodness of fit measures, to identify the best method; it indicated the Arizona DOT method gives the most accurate estimations of Tc. After coming to this conclusion, they also corrected the empirical methods using reference methods and proposed a modified equation to use in ungauged watersheds.

Empirical Tc methods are commonly evaluated using the NRCS velocity method or a graphical method (based on hyetograph and hydrograph) as a reference method. According to McCuen [13], the rainfall-runoff data monitored in watersheds provides the most accurate estimation of Tc. Beven [14] studied the concept of time of concentration and showed that the hydrograph reflects the integral effects of the patterns of inputs and celerities. He explained that applying a definition of Tc based on a hydrograph is more accurate than a definition based on the velocity of flow. McCuen et al. [15] indicated that there is a direct correlation between the Tc value estimated by the velocity method and the time calculated from rainfall and runoff data. While the graphical methods are preferred for evaluating empirical Tc equations, in many locations this data is unavailable and the velocity method is used instead.

De Almeida et al. [16] applied a graphical method to 17 rainfall-runoff events to evaluate and select the best performing empirical equation for a rural watershed in Brazil with a tropical climate. They found Ventura's equation displayed the best performance for the studied watershed. Mudashiru et al. [17] evaluated 21 empirical methods using hyetograph and hydrograph data for an urban basin in Kualampur, Malaysia with an equatorial climate. They indicated Gundlach and Carter methods are suitable for estimating Tc. Grimaldi et al. [18], using rainfall-runoff data, evaluated the performance of empirical methods in four small sub-watersheds in Texas, USA. Their study demonstrated a dramatic variation in Tc values estimated by empirical methods as high as $500 \%$.

Azizian [7] studied the uncertainty of 47 Tc equations and identified the contribution of all input parameters, such as rainfall intensity, land cover-related-coefficients, the scale of topographic and land cover maps, DEM resolution, and streams delineation threshold, in the north of Iran. He found that the empirical equations that are based solely on geomorphological parameters have relatively low uncertainty, but the equations that are based on watershed characteristics, rainfall attributes, and land cover-related coefficients have relatively high uncertainty. 
Rainfall affect Tc through antecedent wetness and rainfall intensity. In wet watersheds, as the soil becomes increasingly saturated (less precipitation infiltered), the runoff will be created more quickly. Comparatively, in dry watersheds, the soil needs more time to reach saturated conditions $[19,20]$. The effect of rainfall patterns on the time of concentration was investigated by Kjeldsen et al. [21], who analyzed hydrographs and indicated that Tc values of a watershed decrease with the increase of rainfall intensity. According to Rao and Delleur [22], the variation in time of concentration depends on the amount, duration, and intensity of rainfall and vegetation.

A review of the literature indicates that there are some gaps in the previous studies:

1- Most of the studies have focused on the analysis of Tc in wet, temperate, and tropic regions. However, the behavior of watersheds in arid regions, despite their significant differences in rainfall pattern, wetness, and vegetation, has been overlooked.

2- Although the analysis of hydrograph and hyetograph can give more accurate Tc as a reference value to evaluate empirical methods, only a few studies have been conducted using recorded rainfall-runoff data. However, due to scarcity of data, none of the studies have focused on arid regions [23,24].

3- The previously mentioned studies applied recorded rainfall-runoff data and evaluated empirical methods at the watershed scale. There is a lack of regional studies evaluating empirical Tc methods

The hypothesis of the current study is that the empirical methods of computing time of concentration in ungauged watersheds result in inaccurate Tc value in an arid region. Thus, this study focuses on identifying the best equation for estimating $T c$ in ungauged sub-watersheds of an arid region located in southern Iran. The values of Tc were estimated by 15 widely used empirical equations in four gauged sub-watersheds. Then, the estimated Tc was compared to the value of Tc obtained from the analysis of the hyetograph and hydrograph data monitored in the sub-watersheds. Then, the performance of each empirical equation was assessed by statistical measures and a ranking-based procedure. Lastly, to improve the accuracy of the empirical methods, the best performing equations were modified based on the results of the graphical method.

In ungauged sub-watersheds of study areas, synthetic hydrographs are typically used to design structures to control stormwater. The accuracy of synthetic hydrograph modeling depends on the accuracy of estimating Tc. Thus, the results of this study will result in improved hydrologic designs.

\section{Background}

Generally, the estimation of Tc is based on seven common definitions: (i) the time needed for water to travel from the hydraulically furthermost point to the watershed outlet; (ii) the time from the end of rainfall excess (effective precipitation) to the inflection point of the falling limb of the total runoff hydrograph; (iii) the time from the center of mass of rainfall excess to the center of mass of direct runoff; (iv) the time from the maximum rainfall intensity to the time of the peak discharge; (v) the time from the center of mass of rainfall excess to the time of the peak of direct runoff; (vi) the time from the center of mass of rainfall excess to the time of the peak of total runoff; and (vii) the time from the start of the total runoff to the time of the peak discharge of the total runoff $[8,13,15,16,25-29]$. Figure 1 illustrates the schematic of a watershed for definition (i), and Figure 2 demonstrates the schematic of hydrograph and hyetograph for definitions (ii), (iii), (iv), (v), (vi), and (vii). 


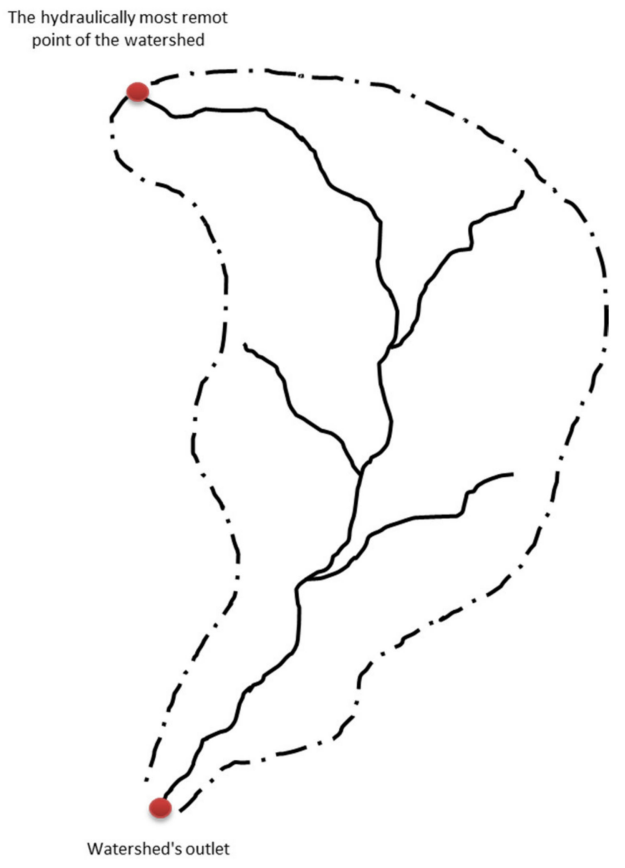

Figure 1. Schematic of a watershed to illustrate definition of Tc (definition i).

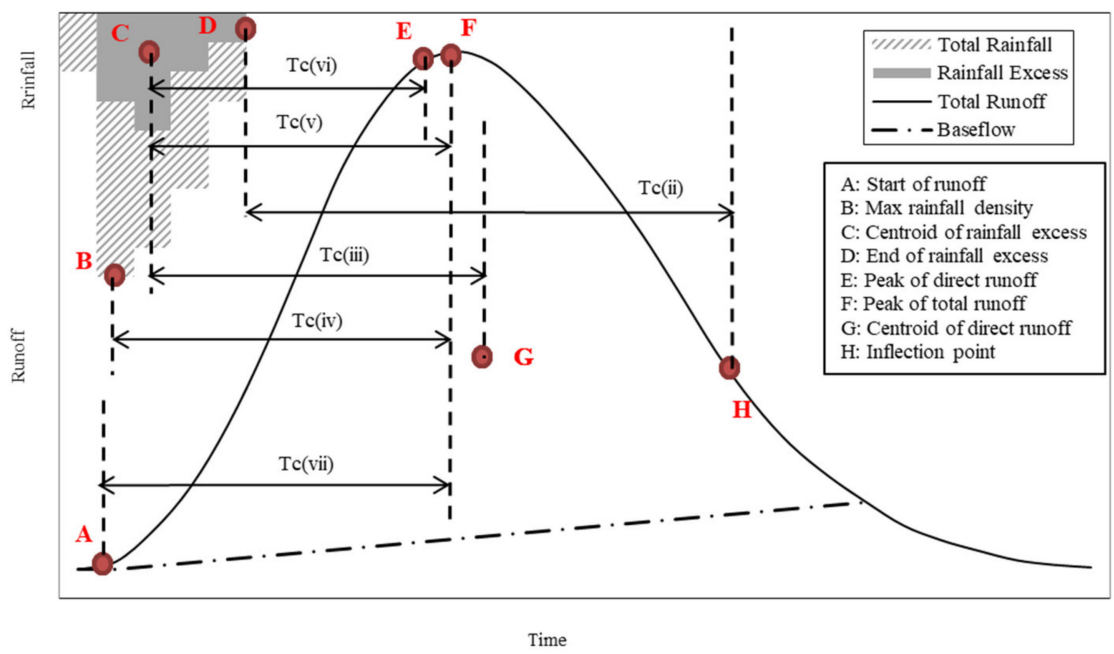

Figure 2. Schematic of rainfall hyetograph and runoff hydrograph to illustrate definitions of Tc. (Definitions ii, iii, iv, v, vi, vii).

Many empirical and semi-empirical methods have been developed from the first definition and are widely used in ungauged watersheds. The procedures for calculating Tc, according to this definition, are based on watershed attributes such as area, slope, channel length, and channel roughness.

The graphical methods are based on the other six definitions, which define Tc according to hyetographs and hydrograph data. Among these six definitions, definition (ii) most accurately reflects the time of concentration because the watershed is likely saturated at the end of rainfall excess [13-16].

In this study, 15 empirical methods, based on the first definition, are compared to one graphical method, where the graphical method is assumed to be the most reliable estimation of Tc. The graphical method that was used is from the second definition: the time from the end of rainfall excess (effective precipitation) to the inflection point of the falling limb of the total runoff hydrograph. This definition was used because it is the most 
acceptable and also because there are widespread alluvial fans with high infiltration in the study area that must be saturated for flooding.

\section{Materials and Methods}

\subsection{Study Area}

The study area is located in the Hormozgan province of southern Iran, neighboring the Persian Gulf. The scope of the case study includes four rural sub-watersheds (Shaghrud, Sikhoran, Chahchakur, and Salubalm) with drainage areas ranging from 131 to 458 located in the central parts of Hormozgan province (Figure 3). Table 1 shows a summary of the physiographic and morphometric characteristics of these sub-watersheds.
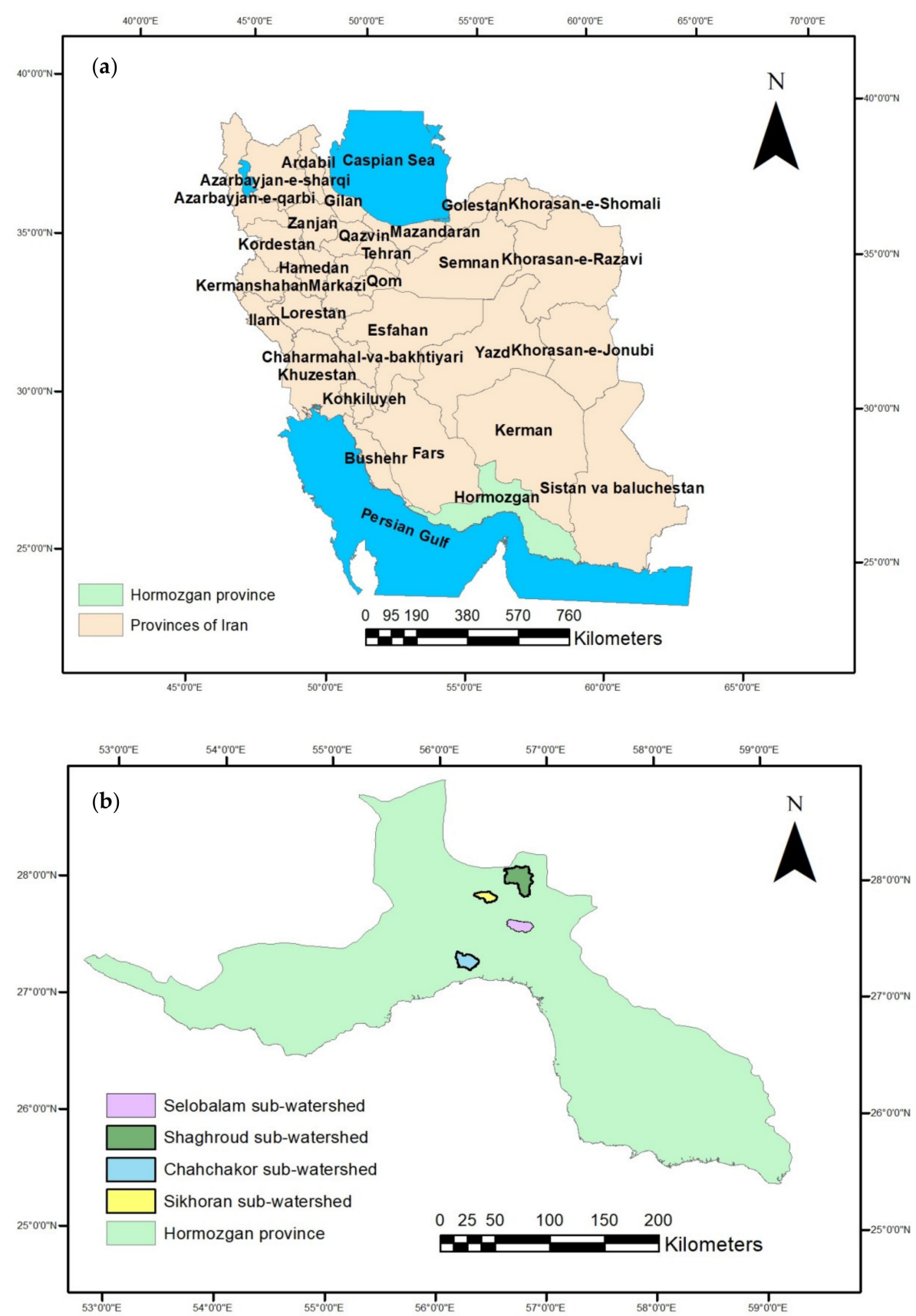

Figure 3. (a) Location of Hormozgan province in Iran. (b) Location of sub-watersheds in Hormozgan province. 
Because only these four sub-watersheds have measuring stations, they were selected for this study. There is a rainfall station in each sub-watershed for monitoring precipitation time series $\left(R_{1}, R_{2}, R_{3}\right.$, and $R_{4}$ shown in Figure 4$)$. The runoff data in each sub-watershed was measured at one gauge located at each outlet $\left(S_{1}, S_{2}, S_{3}\right.$, and $S_{4}$ shown in Figure 4$)$. The rainfall and runoff data used in this study were obtained from the Hormozgan Regional Water Authority Company and Zayandab Consulting Engineers. Rainfall depth data was continuously stored at 15-min intervals for the years 2002-2017, and runoff data was collected at varying intervals according to the rainfall periods. More rainfall stations may result in better analyses of hydrographs, but there is only one rainfall station in each sub-watershed that records data in short intervals. According to Pilgrim et al. [30], the deficiency of rainfall and runoff gauge network in arid regions is one of the challenging issues that makes hydrologic assessment difficult.
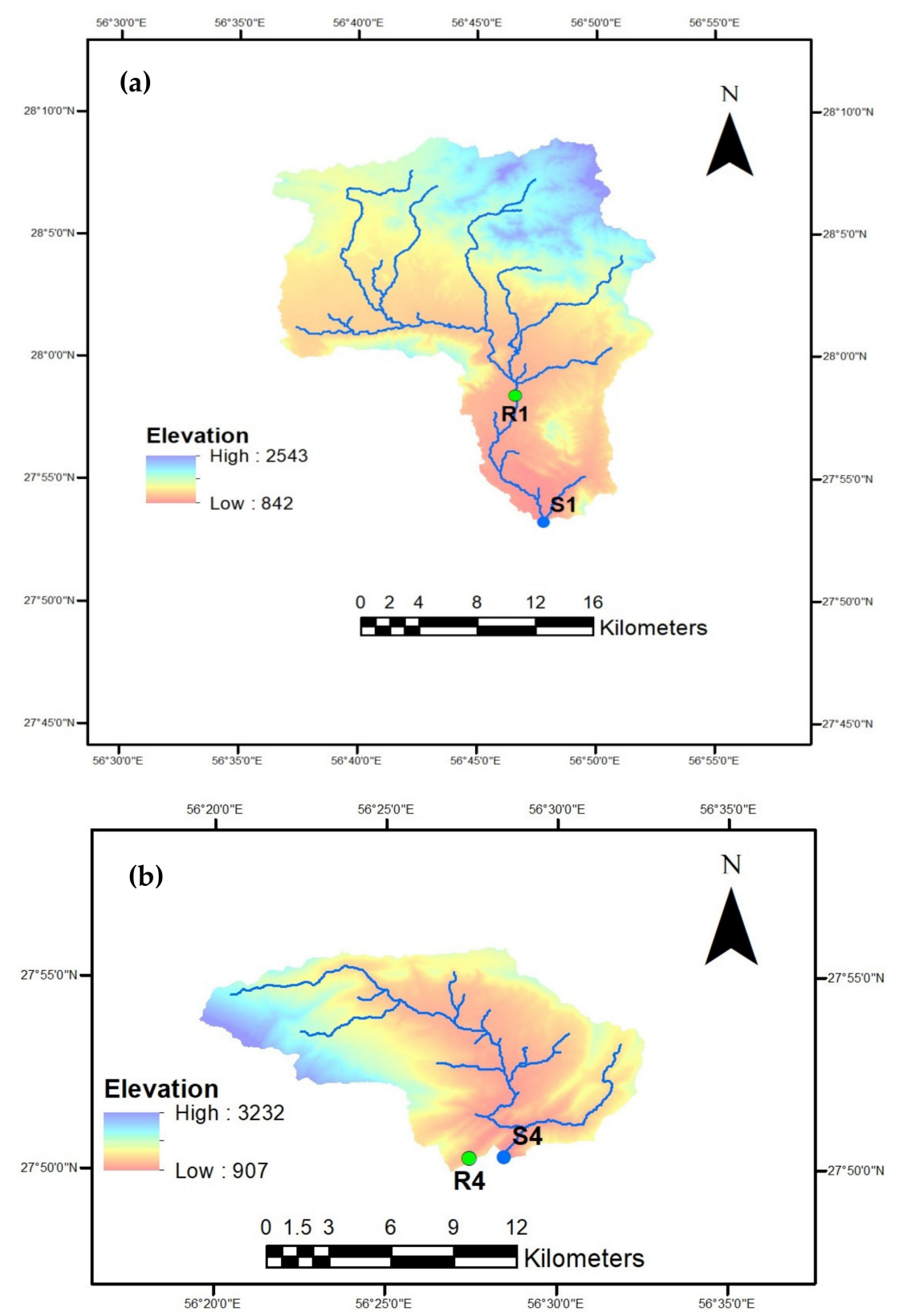

Figure 4. Cont. 

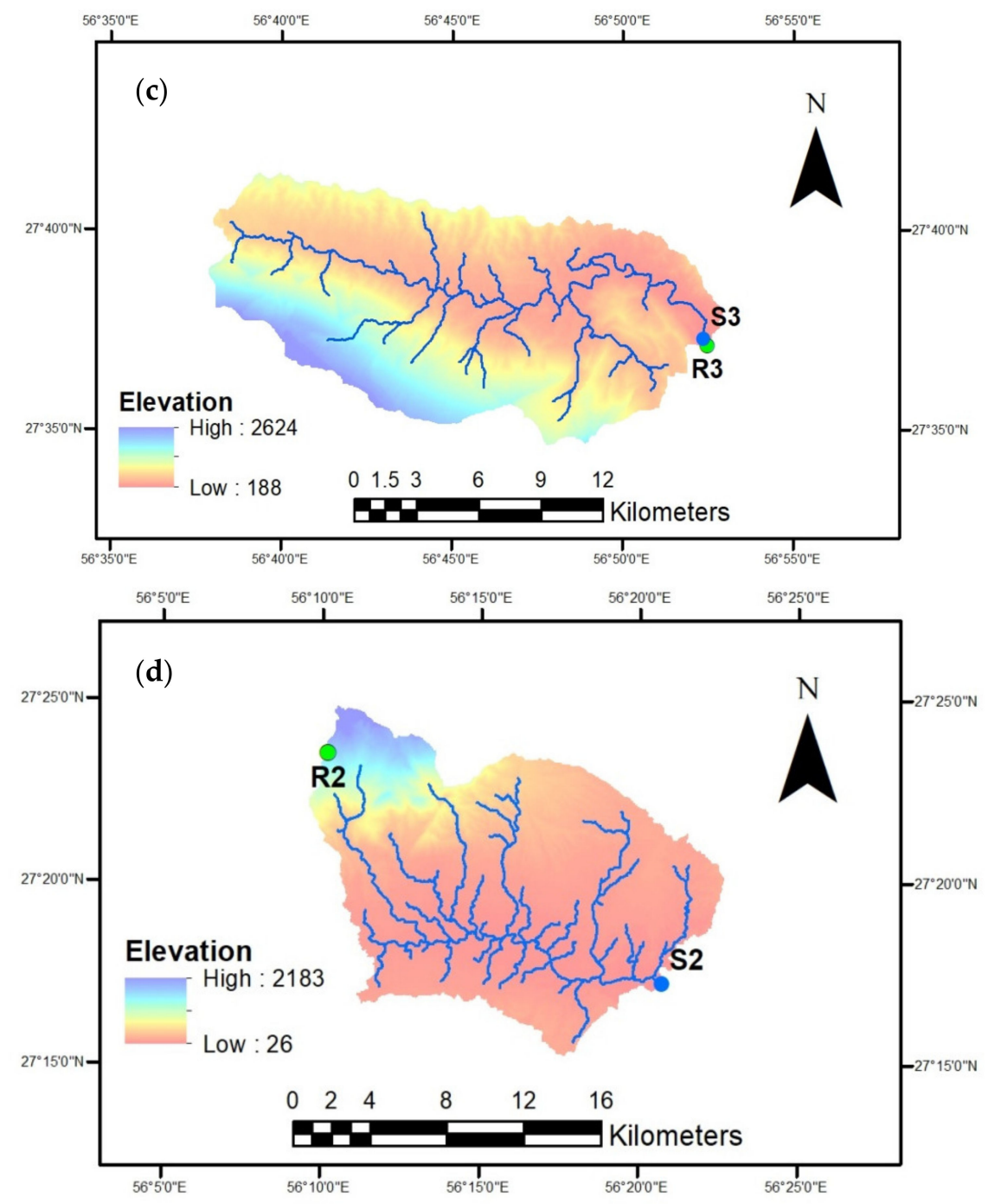

Figure 4. Studied sub-watersheds: (a) Shaghrud, (b) Sikhoran, (c) Salublm, (d) Chahchakur (R1, R2, $\mathrm{R} 3, \mathrm{R} 4)$ rainfall stations (S1, S2, S3, S4) runoff gauge.

The study area is an arid region in Iran receiving $200 \mathrm{~mm}$ of rain per year. The average and maximum daily rainfall, the coefficient of variation of daily rainfall, and annual rainfall in Shaghrud, Sikhoran, Chahchakur, and Salubalm sub-watersheds are presented in Table 2. Almost every year, intense rainfalls occur in the study area that, along with poor pasture land cover, cause torrential floods. Because of this, numerous traditional stormwater management systems have been constructed on tributaries. The main purpose of these systems is diverting small flows towards artificial recharge ponds by the small weirs. Since the existing traditional systems for runoff diversion have been operating for many years and have not been significantly developed, it is assumed they do not have a significant effect on the hydrographs during the period of this study.

In the study area there is alluvial fans that are tens of meters. They have high storage capacities and can absorb large volumes of water. Thus, when the event is sufficient to fully satisfy available alluvial storage the runoff is transmitted downstream. According to the geological maps the area of alluvial fans in the Shaghrud, Sikhoran, Chahchakur, and Salubalm sub-watersheds is $90,20,66$, and $25 \mathrm{Km}^{2}$ respectively and the depth of alluvial fans approximately varies between $3-30 \mathrm{~m}$ in the sub-watersheds. 
Table 1. Summary of general characteristics.

\begin{tabular}{ccccc}
\hline Sub-Watershed & Shaghrud & Sikhoran & Salubalm & Chahchakur \\
\hline Area $\left(\mathrm{Km}^{2}\right)$ & 458 & 131 & 200 & 224 \\
\hline Average slope of sub-watershed $(\%)$ & 23.6 & 45 & 40.6 & 16 \\
\hline Average elevation $(\mathrm{m})$ & 1354 & 1675 & 848 & 263 \\
\hline Main channel length $(\mathrm{Km})$ & 50 & 24 & 37.5 & 30 \\
\hline Average slope of main channel $(\%)$ & 1.2 & 4.4 & 1.1 & 0.8 \\
\hline Perimeter $(\mathrm{m})$ & 154 & 72 & 88 & 99 \\
\hline Compactness coefficient $(\mathrm{Cc})$ & 2.0 & 1.8 & 1.8 & 1.9 \\
\hline Stream length $(\mathrm{Km})$ & 1567 & 594 & 907 & 1243 \\
\hline Drainage density $\left(\mathrm{Km} / \mathrm{Km}^{2}\right)$ & 3.4 & 4.5 & 4.5 & 5.6 \\
\hline
\end{tabular}

Table 2. Characteristics of daily and annual rainfall in sub-watersheds.

\begin{tabular}{ccccc}
\hline Sub-Watershed & Shaghrud & Sikhoran & Salubalm & Chahchakur \\
\hline Average daily rainfall $(\mathrm{mm})$ & 0.44 & 0.68 & 0.79 & 0.47 \\
\hline Maximum daily rainfall $(\mathrm{mm})$ & 75 & 147 & 198 & 155 \\
\hline Minimum daily rainfall $(\mathrm{mm})$ & 0 & 0 & 0 & 0 \\
\hline Coefficient of variation $(\mathrm{CV})$ & 7.4 & 7.7 & 9.2 & 10.9 \\
\hline Annual rainfall $(\mathrm{mm})$ & 159 & 247 & 287 & 172 \\
\hline
\end{tabular}

\subsection{Empirical Methods}

After review, among many empirical methodologies proposed to estimate Tc in literature, 15 commonly used and popular methods, which have been proposed for non-urban watersheds, were selected to test in this study (Table 3). Some empirical methods are based on land cover coefficients (e.g., manning's roughness coefficient, curve number, and retardance factors), causing the estimations to be heavily dependent on the modeler's assumptions of those input coefficients. Applying such methods can lead to a great level of uncertainty, and modelers tend to avoid using these methods $[7,11]$. Thus, simple methods were selected that generally use measured input data. For a comprehensive review of all empirical methods, the reader is referred to [7,26,28,31-33].

Some assumptions are inherent in each empirical method that limit their application (e.g., watershed area, slope, and length of the main channel, dominant flow regime). Considering these physical restrictions may not lead to selecting a joint method for all sub-watersheds. Furthermore, according to de Almeida et al. [16], the majority of empirical methods have been developed for watersheds in temperate regions; with there not being a method developed in arid regions, we face a limitation in selection. The previous studies indicated ignoring the restrictions of empirical equations generally leads to a degree of bias in the estimation of Tc; however, if the modification on formulation is done properly, the bias will be minimized [10-12]. In this study, empirical equations that were suitable for non-urban watersheds were selected and other restrictions were ignored.

\subsection{Graphical Method}

The time of concentration was calculated via a graphical analysis of the hyetograph and hydrograph data for the selected events. With the hydrological response being sensitive to the variability of rainfall, the selection of events considering different depths, intensity, and duration of precipitations are important in understanding the watershed's behavior against different patterns of inputs [33,34]. Furthermore, according to Hadadin (2013) and de Almeida (2017) [22,35], another important issue is selecting single rainfall events that 
provide single peak hydrographs, since the separation of a hydrograph and its rainfall in multiple events is very difficult and causes errors in calculating Tc.

During the period 2002-2017, 37 recorded rainfall-runoff events were analyzed. Using the aforementioned criteria, 33 rainfall-runoff events were selected for this study. To calculate the effective precipitation hyetograph, the phi-index method was applied [36-42]. In addition, to obtain a baseflow separation, in this study, the constant discharge method was used. This method assumes base flow is constant during the storm hydrograph and the minimum streamflow immediately before the rising limb is used as the constant value [41].

\subsection{Ranking and Improvement of Empirical Methods}

In order to evaluate the performance of each approach and select the best performing empirical method for the region, a ranking-based selection procedure, which was suggested by Sharifi and Hosseini [11], was applied. First, the values of Tc in the four sub-watersheds obtained from the graphical method were compared to the empirical methods. Next, the difference between Tc values obtained from the graphical method and empirical formulas were assessed using four goodness of fit measures. For the evaluation of models and equations, ASCE recommended applying both statistical measures and graphical plots [42]. In addition, according to Legates [43] a complete evaluation of model performance should include at least one relative error measure, one absolute (or square) error measure. Thus, we used the mean absolute percentage of errors (MAPE) as a relative error measure, the root mean sum of squared errors (RMSE) as square error measure, and the coefficient of correlation $(\mathrm{R})$ of linear regression for evaluation by the graphical plot. In addition to these essential measures, we applied the sum of errors (SE) to evaluate the possible bias (under or over estimation). Then, the methods were ranked by each of the statistical measures. The rankings were summed across measures to give an overall ranking of each method.

Once each empirical method was evaluated, the best methods were selected for optimization. Optimization was performed by adjusting the equations to minimize the bias between the empirical and graphical Tc estimations [11,16]. To modify the equations, a curve fitting software was used. DataFit gives the user the ability to create regression models [44]. This software was used to correct the values of coefficients and exponents for the selected equations.

To evaluate the validity of modified equations, the graphical analysis of residuals and cross-validation for overfitting was applied. The residuals for the reference values of the time of concentration were plotted to check their randomness. There are two wellknown methods to detect overfitting, including K-fold and leave-one-out cross validation. Because the amount of rainfall-runoff data applied in this study is small, the leave-oneout cross validation which is suitable for small-sized dataset was selected for evaluating overfitting [45-47]. 
Table 3. Summary of the selected empirical methods for estimating Tc.

\begin{tabular}{|c|c|c|}
\hline Method & Equation & Remarks \\
\hline $\begin{array}{l}\text { Bransby Williams } \\
\text { (ASDOT 1995) }\end{array}$ & $\mathrm{T}_{\mathrm{C}}=0.605 \mathrm{~L}\left(100 \mathrm{~S}_{\mathrm{c}}\right)^{-0.2} \mathrm{~A}^{-0.1}$ & Developed for rural watersheds \\
\hline Kirpich (Tennessee) (1940) & $\mathrm{T}_{\mathrm{C}}=0.066 \mathrm{~L}^{0.77} \mathrm{~S}^{-0.385}$ & $\begin{array}{c}\text { Developed for small rural watersheds in } \\
\text { Tennessee } \\
\left(0.004-0.453 \mathrm{Km}^{2}\right) \text { and }(0.03<\mathrm{S}<0.1)\end{array}$ \\
\hline Chow (1988) & $\mathrm{T}_{\mathrm{C}}=0.1602 \mathrm{~L}^{0.64} \mathrm{~S}_{\mathrm{c}}{ }^{-0.32}$ & $\begin{array}{l}\text { Developed for rural watersheds in the USA } \\
\left(0.01-18.5 \mathrm{Km}^{2}\right) \text { and }\left(0.005<\mathrm{S}_{\mathrm{c}}<0.09\right)\end{array}$ \\
\hline $\begin{array}{l}\text { California Culverts Practice } \\
\text { (CDH, 1960) }\end{array}$ & $\mathrm{T}_{\mathrm{C}}=\left(0.871 \frac{\mathrm{L}^{3}}{\Delta \mathrm{H}}\right)^{0.385}$ & $\begin{array}{l}\text { Developed for small mountainous } \\
\text { watersheds in California }\end{array}$ \\
\hline Arizona DOT (1993) & $\mathrm{T}_{\mathrm{C}}=0.0097956 \mathrm{~A}^{0.1}\left(1000 \mathrm{LL}_{\mathrm{ca}}\right)^{0.25} \mathrm{~S}_{\mathrm{c}}{ }^{-0.2}$ & $\begin{array}{c}\text { Developed for agricultural watersheds } \\
\text { Watershed area }<8.09 \mathrm{Km}^{2}\end{array}$ \\
\hline Johnstone-Cross (1949) & $\mathrm{T}_{\mathrm{C}}=0.4623 \mathrm{~L}^{0.5} \mathrm{~S}_{\mathrm{c}}-0.25$ & $\begin{array}{l}\text { Developed for rural watersheds in the USA } \\
\qquad\left(64.8-4206.1 \mathrm{Km}^{2}\right)\end{array}$ \\
\hline Temez (1987) & $\mathrm{T}_{\mathrm{C}}=0.3 \mathrm{~L}^{0.76} \mathrm{~S}_{\mathrm{c}}-0.19$ & Developed for natural watersheds in Spain \\
\hline Haktanir and Sezen (1990) & $\mathrm{T}_{\mathrm{C}}=0.7473 \mathrm{~L}^{0.841}$ & $\begin{array}{l}\text { Developed for watersheds in Turkey } \\
\qquad\left(11-9867 \mathrm{Km}^{2}\right)\end{array}$ \\
\hline Giandotti (1934) & $\mathrm{T}_{\mathrm{C}}=\frac{(4 \sqrt{\mathrm{A}}+1.5 \mathrm{~L})}{0.8 \sqrt{\mathrm{H}_{\mathrm{m}}}}$ & $\begin{array}{l}\text { Developed for agricultural watersheds in } \\
\text { central and northern Italy } \\
\left(170-70,000 \mathrm{Km}^{2}\right)\end{array}$ \\
\hline $\begin{array}{c}\text { Ventura } \\
\text { (Mata-Lima et al., 2007) }\end{array}$ & $\mathrm{T}_{\mathrm{C}}=7.62\left(\mathrm{AS}_{\mathrm{c}}\right)^{0.5}$ & Developed for rural watersheds in Italy \\
\hline Pilgrim and Mac Dermott (1982) & $\mathrm{T}_{\mathrm{C}}=0.76 \mathrm{~A}^{0.38}$ & $\begin{array}{l}\text { Developed for rural watersheds in eastern } \\
\text { New South Wales }\end{array}$ \\
\hline Pasini (1914) & $\mathrm{T}_{\mathrm{C}}=0.108(\mathrm{AL})^{0.333} \mathrm{~S}_{\mathrm{c}}{ }^{-0.5}$ & Developed for rural watersheds in Italy \\
\hline Williams (1922) & $\mathrm{T}_{\mathrm{C}}=0.272 \mathrm{~A}^{0.4} \underset{\mathrm{D}}{\mathrm{L}} \mathrm{S}_{\mathrm{C}}-0.2$ & $\begin{array}{l}\text { Developed for watersheds in India } \\
\text { (Watershed area }<129.5 \mathrm{Km}^{2} \text { ) }\end{array}$ \\
\hline Dooge (1973) & $\mathrm{T}_{\mathrm{C}}=0.365 \mathrm{~A}^{0.41} \mathrm{~S}_{\mathrm{c}}-0.17$ & $\begin{array}{l}\text { Developed for rural watersheds in Ireland } \\
\qquad\left(145-948 \mathrm{Km}^{2}\right)\end{array}$ \\
\hline $\begin{array}{l}\text { Corps of Engineers } \\
\text { (Linsley et al., 1977) }\end{array}$ & $\mathrm{T}_{\mathrm{C}}=0.191 \mathrm{~L}^{0.76} \mathrm{~S}_{\mathrm{c}}-0.19$ & $\begin{array}{l}\text { Developed for rural watersheds in the USA } \\
\text { (Watershed area }<12 \mathrm{Km}^{2} \text { ) }\end{array}$ \\
\hline
\end{tabular}

Note: $\mathrm{A}=$ area $\left(\mathrm{Km}^{2}\right)$; $\mathrm{Sc}=$ average slope of main channel $(\mathrm{m} / \mathrm{m}) ; \mathrm{S}=$ average slope of watershed $(\mathrm{m} / \mathrm{m}) ;$ Hm = average elevation of watershed $(\mathrm{m}) ; \Delta \mathrm{H}=$ elevation difference between start and endpoint of the main channel $(\mathrm{m}) ; \mathrm{D}=$ equivalent diameter of the catchment $(\mathrm{Km})$; $\mathrm{L}=$ length of main channel $(\mathrm{Km})$; $\mathrm{Lca}=$ length measured from the concentration point along $\mathrm{L}$ to a point on $\mathrm{L}$ that is perpendicular to the watershed centroid $(\mathrm{Km})$.

\section{Results and Discussion}

\subsection{Empirical Methods}

The Tc values obtained by applying the empirical methods are shown in Table 4 . These results are highly variable. The highest Tc values for the four sub-watersheds came from the Haktanir and Sezen and Passini equations ranging between 7.5 and $27.9 \mathrm{~h}$. The lowest Tc values came from Kirpich's equation and ranged between 1.0 and $2.3 \mathrm{~h}$. The mean Tc values estimated for the Shaghrud, Sikhoran, Salubalm, and Chahchakur subwatersheds were $11.3,4.6,8.7$, and $8.8 \mathrm{~h}$, respectively. The mean relative differences for Tc obtained by different methods ranged from -82 to $157 \%$. Fang et al. [33] obtained similar mean relative differences ranging between -38 and $207 \%$ for central Texas. As noted in previous studies, most empirical methods have been developed for a particular region with specific attributes, and it is necessary to assess the accuracy of these methodologies in other areas [46]. 
Table 4. Values of Tc in sub-watersheds determined by applying empirical equations.

\begin{tabular}{ccccc}
\hline \multirow{2}{*}{ Method } & \multicolumn{3}{c}{ Tc (h) } \\
\cline { 2 - 5 } & Shaghrud & Sikhoran & Salubalm & Chahchakur \\
\hline Bransby Williams & 15.8 & 6.6 & 13.1 & 11.0 \\
Kirpich & 2.3 & 1.0 & 1.5 & 1.8 \\
Chow & 8.1 & 3.3 & 6.9 & 6.6 \\
California Culverts Practice & 6.5 & 2.1 & 4.4 & 3.0 \\
Arizona DOT & 7.5 & 3.1 & 5.9 & 5.8 \\
Johnstone-Cross & 9.9 & 4.9 & 8.7 & 8.5 \\
Temez & 13.6 & 6.1 & 11.1 & 10.0 \\
Haktanir and Sezen & 20.1 & 10.8 & 15.7 & 13.1 \\
Giandotti & 5.5 & 2.5 & 4.8 & 8.1 \\
Ventura & 24.8 & 6.9 & 17.1 & 21.3 \\
Pilgrim and Mac Dermott & 7.8 & 4.8 & 5.7 & 5.9 \\
Pasini & 27.9 & 7.5 & 20.1 & 22.7 \\
Williams & 6.3 & 2.6 & 5.2 & 4.4 \\
Dooge & 9.5 & 4.6 & 6.9 & 7.6 \\
Corps of Engineers & 3.6 & 1.6 & 2.9 & 2.6 \\
\hline Mean & 11.3 & 4.6 & 8.7 & 8.8 \\
\hline
\end{tabular}

\subsection{Graphical Method}

The graphical method was applied to 33 events that occurred in the four sub-watersheds of the study area. The graphical Tc was determined by calculating the difference between rainfall excess and the inflection point. To demonstrate the use of the method, the event on 25 March 2017 in the Salubalm sub-watershed is presented in Figure 5. Table 5 shows the characteristics of events and the Tc values derived from the graphical method for each event. The duration of rainfall events ranges from $1-28 \mathrm{~h}$, and rainfall depth differs from $5-100 \mathrm{~mm}$. In addition, the highest rainfall intensity for events is between $4-76 \mathrm{~mm} / \mathrm{h}$. The Tc values obtained from the graphical analysis demonstrated some variability. To define a unique value for the graphical Tc method for each sub-watershed, the average was calculated. The results show the average $T_{C}$ value in the Salublm and Sikhoran sub-watersheds is shorter than the Shaghrud and Chahchakur. Furthermore, the longest and shortest Tc values belong to Shaghrud and Sikhoran sub-watersheds respectively.

Comparing the daily and annual rainfall in the region indicates that in Shaghrud and Chahchakur sub-watershed the annual rainfalls are lower than other sub-watersheds. According to Sehler et al. [47] land cover and precipitation are the most important parameters affecting soil moisture, and in drier and less vegetative climates, rainfall has the strongest relationship with moisture. The Shaghrud and Chahchakur sub-watersheds that receive less precipitation are drier than the other sub-watersheds. During a rainfall event, it takes the Shaghrud and Chahchakur sub-watersheds more time to reach saturation point, and this leads to longer Tc. Furthermore, the average daily rainfall intensity in Salublm and Sikhoran is higher than in other sub-watersheds. Thus, according to Kjeldsen et al. [21] the Tc in these sub-watersheds should be shorter.

Previous studies have shown that some morphometric and physiographic characteristics of watersheds affect Tc. Larger drainage density and slope can lead to shorter Tc, while larger compactness coefficient, stream length, and main channel length can cause longer Tc [28,48-50]. The value of Tc in Shagrud sub-watersheds is longer than other sub-watersheds. This is due to the larger compactness coefficient, stream length, main channel length, and/or smaller drainage density. In addition, Tc in Sikhoran sub-watershed is shorter than other sub-watersheds. This is because of the smaller main channel length, compactness coefficient, stream length, and/or steep slope of the main channel. 


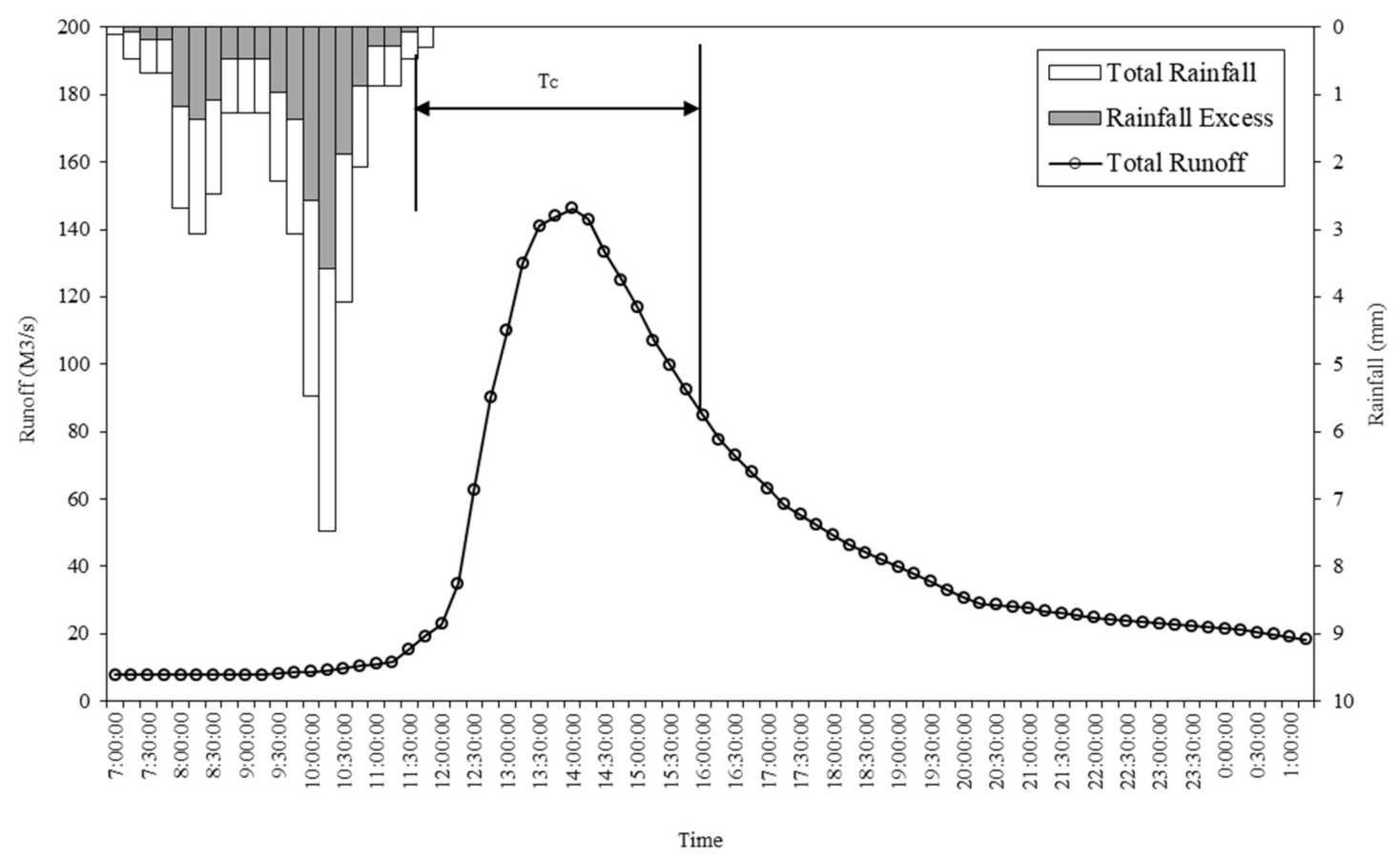

Figure 5. Hydrograph of the 25 March 2017 event in Salubalm sub-watershed.

The comparison of the average Tc value calculated using the graphical method and the average Tc value estimated by empirical methods in Tables 4 and 5 shows, only in the Sikhoran sub-watershed, the average Tc values derived from the empirical and graphical methods are close to each other; in the other sub-watersheds, the empirical Tc values are significantly longer. As the majority of empirical methods were developed in temperate regions, with longer rainfall duration, lower rainfall intensity, higher soil moisture, and/or richer vegetation, the application of these methods in arid regions result in longer travel time [16].

\subsection{Performance Evaluation of Empirical Methods in Sub-Watersheds}

Due to the shortage of events applied in this study, particularly for Chahchakur subwatershed, the use of statistical measures and the coefficient of correlation to evaluate the performance of empirical methods in the sub-watershed scale are not reliable. Thus, the relative difference between the mean graphical Tc and the values estimated by empirical methods were applied as the criterion for the evaluation of methods in each sub-watershed. As may be seen from Table 6, the relative difference in studied sub-watersheds varied from -75 to $381 \%$. Among the equations used for this study, Barnaby Williams, Johnstone-Cross, Temez, Haktanir and Sezen, Ventura, Pilgrim and Mac Dermott, and Pasini and Dooge all consistently overestimated Tc in each of the four sub-watersheds. The Kirpich and Corps of Engineers consistently underestimated the Tc. The remaining equations were inconsistent between the sub-watersheds in their over or under-estimation of Tc. The Giandotti method gives the best estimation of Tc in the Shaghrud and Salubalm sub-watersheds (with an error of $-6 \%$ and $-1 \%$ respectively), and in the Sikhoran and Chahchkur sub-watersheds the Doog and Arizona DOT methods estimate the value of Tc more accurately (with an error of $9 \%$ ). In addition, Passini, Ventura and Haktanir, and Sezen are the least accurate equations for estimating Tc in the sub-watersheds. To find the method(s) that properly estimates Tc in all ungauged sub-watersheds, a regional evaluation will be done in the next section. 
Table 5. Values of $\mathrm{T}_{C}$ in sub-watersheds determined from the graphical method.

\begin{tabular}{|c|c|c|c|c|c|c|c|}
\hline $\begin{array}{c}\text { Sub- } \\
\text { Watershed }\end{array}$ & Event Number & Event Date & $\begin{array}{c}\text { Rainfall } \\
\text { Duration (h) }\end{array}$ & $\begin{array}{c}\text { Rainfall } \\
\text { Depth }(\mathrm{mm})\end{array}$ & $\begin{array}{l}\text { Maximum } \\
\text { Rainfall } \\
\text { Intensity } \\
(\mathrm{mm} / \mathrm{h})\end{array}$ & $\begin{array}{l}\text { Maximum } \\
\text { Peak Flood } \\
\left(\mathrm{m}^{3} / \mathrm{s}\right)\end{array}$ & Tc (h) \\
\hline \multirow{9}{*}{ Sikhoran } & 1 & 4 November 2002 & 3.25 & 99 & 76 & 38 & 4.3 \\
\hline & 2 & 29 October 2003 & 9.5 & 29.2 & 14 & 95.5 & 4.5 \\
\hline & 3 & 27 January 2004 & 2 & 17 & 29.6 & 13 & 4.5 \\
\hline & 4 & 27 February 2010 & 6.5 & 38.5 & 36.4 & 10.1 & 4.5 \\
\hline & 5 & 1 February 2013 & 9 & 40 & 12 & 24.4 & 3.8 \\
\hline & 6 & 14 March 2014 & 7.5 & 29.1 & 65.2 & 391 & 4.5 \\
\hline & 7 & 12 March 2015 & 14 & 32.9 & 16 & 20.3 & 3.8 \\
\hline & 8 & 11 November 2015 & 15 & 41.4 & 17.6 & 25.2 & 4.0 \\
\hline & 9 & 3 January 2016 & 4.75 & 15.9 & 15.2 & 28.7 & 4.3 \\
\hline Mean Tc & & & & & & & 4.2 \\
\hline \multirow{9}{*}{ Shaghrud } & 1 & 28 July 2007 & 2.5 & 13.2 & 24.8 & 19.6 & 5.8 \\
\hline & 2 & 30 March 2009 & 3.25 & 15.4 & 10 & 9.7 & 5.8 \\
\hline & 3 & 31 March 2009 & 6.25 & 10.6 & 9.6 & 74.8 & 6.0 \\
\hline & 4 & 8 November 2009 & 1.25 & 17 & 18.8 & 61.1 & 5.8 \\
\hline & 5 & 3 March 2012 & 16 & 40 & 12.8 & 48.8 & 5.5 \\
\hline & 6 & 3 March 2013 & 6.75 & 21.4 & 14.4 & 64.4 & 5.5 \\
\hline & 7 & 12 March 2015 & 10.5 & 50 & 18.4 & 27 & 6.0 \\
\hline & 8 & 26 February 2017 & 3 & 5.4 & 6.4 & 17.3 & 5.5 \\
\hline & 9 & 20 March 2017 & 7.4 & 7.4 & 3.6 & 46.2 & 6.0 \\
\hline Mean Tc & & & & & & & 5.8 \\
\hline \multirow{11}{*}{ Salubalm } & 1 & 27 March 2003 & 3.5 & 24.8 & 74 & 13.8 & 5.0 \\
\hline & 2 & 15 January 2004 & 8.25 & 11.3 & 13.2 & 41.3 & 4.5 \\
\hline & 3 & 20 February 2007 & 3.75 & 12.3 & 16 & 62.2 & 5.0 \\
\hline & 4 & 17 March 2007 & 5.75 & 5 & 6 & 13.8 & 4.8 \\
\hline & 5 & 27 October 2007 & 4 & 55.9 & 40.4 & 43 & 5.0 \\
\hline & 6 & 30 March 2009 & 6.25 & 22.1 & 10.4 & 19.5 & 4.5 \\
\hline & 7 & 8 December 2009 & 4.5 & 83.4 & 48.4 & 240 & 4.8 \\
\hline & 8 & 9 December 2009 & 13.5 & 125 & 71.6 & 362 & 5.0 \\
\hline & 9 & 5 February 2010 & 5 & 48.2 & 55.2 & 343 & 4.8 \\
\hline & 10 & 21 January 2017 & 37.5 & 25.4 & 16 & 165 & 5.3 \\
\hline & 11 & 25 March 2017 & 8.75 & 28.2 & 15.6 & 146 & 4.8 \\
\hline Mean Tc & & & & & & & 4.9 \\
\hline \multirow{4}{*}{ Chahchkur } & 1 & 30 March 2009 & 5.5 & 58.9 & 40.8 & 33.2 & 5.8 \\
\hline & 2 & 31 March 2009 & 4.5 & 44 & 29.6 & 49 & 5.3 \\
\hline & 3 & 8 December 2009 & 5 & 34.8 & 48.2 & 34.9 & 5.3 \\
\hline & 4 & 27 February 2010 & 7 & 34.9 & 12.4 & 151 & 4.8 \\
\hline Mean Tc & & & & & & & 5.3 \\
\hline
\end{tabular}

\subsection{Regional Performance Evaluation of Empirical Methods}

To evaluate the performance of each equation in the study area, statistical measures were calculated by comparing 33 Tc values from the graphical method, event to event, and those estimated by the empirical equations. Statistical measures were calculated for regional evaluation of each empirical method using these 33 values (Table 7).

The sum of errors (SE) indicates that 5 methods, Kirppich, California, Giandotti, Williams, and Corps of Engineers, underestimate Tc value, and the rest of the methods overestimate Tc value in the sub-watersheds of the region. Unfortunately, some local modelers traditionally apply Kirppich's equation without evaluation to simulate synthetic hydrograph in ungauged sub-watersheds. This can lead to overestimation of the peak flood discharge. Furthermore, according to the values of SE, the Williams, Giandotti, Arizona DOT, and California methods give the least possible bias (8-26 h) in their estimations for the study area sub-watersheds.

Regarding the square error measures (RMSE), if the estimations of empirical methods are perfect, RMSE will be zero. Comparing the empirical methods and reference method by this measure indicates that the errors for Williams, Pilgrim and Mac Dermott, Giandotti, and Arizona DOT methods are smaller than other methods, ranging from about $0.9-1.3 \mathrm{~h}$. 
The mean absolute percentage of error measure (MAPE) is used as a relative measure of the bias. As may be seen from Table 7, the Williams, Pilgrim and Mac Dermott, Giandotti and Arizona DOT methods give the minimum of bias (17-24\%) in their estimations for the study area sub-watersheds.

In addition, evaluation of the scatterplot of Tc estimated by empirical methods and the graphical method were used in combination with statistical measures. According to the value of coefficient of correlation, Kippich, Doog, and Ventura give the best estimation of Tc for the study area sub-watersheds ( $\mathrm{R}$ is larger than 0.90).

The evaluation by RMSE, and MAPE had similar results. They suggest the Williams, Pilgrim and Mac Dermott, Giandotti, and Arizona DOT methods are the best methods to estimate Tc in the ungauged sub-watersheds of the region. However, the Williams, Giandotti, and Arizona DOT methods were also approved as the best methods in evaluation by SE. Despite this, the results of evaluation by the coefficient of correlation are completely different from statistical measures. Although the Kippich, Doog, and Ventura methods give the best $\mathrm{R}$, their estimations are with a bias between 41 to $235 \%$ and have a mean error of about 2-14 h. Furthermore, Giandotti's method is suggested one of the best methods in evaluation by SE, RMSE and MAPE, but it gives a poor correlation $(R=0.678)$ between empirical and graphical Tc values that results in a poor overall performance.

The results show the statistical measures and coefficient of correlation propose different empirical methods for estimating the Tc value in the ungauged sub-watersheds. In this condition, to select the best method(s), Sharifi and Hosseini [11] proposed the ranking based strategy. According to this strategy, each empirical method was ranked in both statistical measures and the coefficient of correlation. Then, the rankings were summed to give the overall ranking for each empirical method. The overall ranking of the methods gave a general and comprehensive evaluation that was applied to select the best method(s). For a complete review of the different evaluation methods and statistical goodness-of-fit measures, the reader is referred to [11,12,43,51-56].

The sum of rankings in Table 7 revealed that three methods, (1) Pilgrim and Mac Dermott, (2) Williams, and (3) Arizona DOT, gave more accurate estimations, and they can be applied in estimating Tc in ungauged study area sub-watersheds. The (1) Haktanir and Sezen, (2) Pasini, and (3) Bransby Williams methods performed considerably worse than the other equations.

Previous studies in temperate northeast Iran also showed that the original Arizona DOT formulas estimated Tc without significant error [11]. Similarly, previous studies in the humid region of Iran also indicated that the Bransby Williams method had the best performance [9].

Although there is the variability in area, length, and slope in the studied sub-watersheds, it seems the lack of restrictions in application of the Pilgrim and Mac Dermott method resulted in its good performance. Despite the restriction in application of the Arizona DOT and Williams methods to watersheds with the area of smaller than 8 and $129 \mathrm{Km}^{2}$, these methods gave acceptable estimations of Tc. The equations of these two methods differ from other methods because they are function of shape factors (Lca and L/D). Previous studies indicated that shape factors that show elongation of watersheds affect Tc and it appears considering shape factors in Arizona DOT and Williams methods improved their performance [50,51]. Although the Pilgrim and Mac Dermott, Williams and Arizona DOT methods gave the best performance compared to the other empirical methods they still had an error of -37 to $34 \%$ (Table 6). In the next section, these errors will be reduced by modifying the original equations. 
Table 6. Relative differences between mean Tc achieved by the graphical method and by empirical methods.

\begin{tabular}{|c|c|c|c|c|}
\hline \multirow{2}{*}{ Method } & \multicolumn{4}{|c|}{ Difference $\%$} \\
\hline & Shaghrud & Sikhoran & Salubalm & Chahchakur \\
\hline $\begin{array}{l}\text { Bransby } \\
\text { Williams }\end{array}$ & 172 & 58 & 167 & 108 \\
\hline Kirpich & -60 & -75 & -69 & -65 \\
\hline Chow & 39 & -21 & 41 & 25 \\
\hline $\begin{array}{c}\text { California } \\
\text { Culverts Practice }\end{array}$ & 12 & -50 & -11 & -43 \\
\hline Arizona DOT & 29 & -26 & 21 & 9 \\
\hline Johnstone-Cross & 70 & 18 & 78 & 60 \\
\hline Temez & 134 & 45 & 127 & 88 \\
\hline $\begin{array}{l}\text { Haktanir and } \\
\text { Sezen }\end{array}$ & 246 & 158 & 221 & 146 \\
\hline Giandotti & -6 & -41 & -1 & 53 \\
\hline Ventura & 328 & 65 & 249 & 301 \\
\hline $\begin{array}{c}\text { Pilgrim and Mac } \\
\text { Dermott }\end{array}$ & 34 & 15 & 16 & 12 \\
\hline Pasini & 381 & 79 & 310 & 329 \\
\hline Williams & 9 & -37 & 7 & -17 \\
\hline Dooge & 65 & 9 & 41 & 44 \\
\hline $\begin{array}{l}\text { Corps of } \\
\text { Engineers }\end{array}$ & -38 & -62 & -40 & -50 \\
\hline
\end{tabular}

\subsection{Improving the Accuracy of the Top Methods}

To minimize the bias and improve the accuracy, previous studies modified the formulation of the empirical method by correcting the coefficients and exponents of the original equation [10-12,57]. The coefficients and exponents of the equations were adjusted, and the modified equations were developed for using in the ungauged study area sub-watersheds.

Table 8 shows the modified equations, their coefficients of correlation, and the sum of residuals. The sum of residuals equaling zero indicates the equation is the best fit. However, the sum of residuals for all three modified equations is near zero. Figure 6 illustrates the Tc values estimated by these equations versus the Tc values calculated by the graphical method and the residual distribution for each modified equation. Generally, a visual review of the residual plots shows that the residuals for each modified equation are unbiased and have an approximately constant variance.

Table 9 displays the difference between mean Tc calculated by the graphical method and Tc estimated by three modified empirical methods. This table shows the relative differences range from -6.6 to $4.2 \%$, whereas, before modification, the relative differences ranged from -37 to $34 \%$ (Table 6 ). In addition, the comparison of Tables 6 and 9 indicates that in all sub-watersheds the correction of Arizona DOT and Williams methods was better than the correction of the Pilgrim and Mac Dermott method. The Arizona DOT and Williams's equations, which use shape factors, slope, and stream length in addition to area, resulted in better fitting compared to the Pilgrim and Mac Dermott method. Thus, it is concluded that selection of empirical models which are function of shape factors, slope, stream length and area with a proper correction can give better estimation of Tc in the ungauged study area sub-watersheds. 

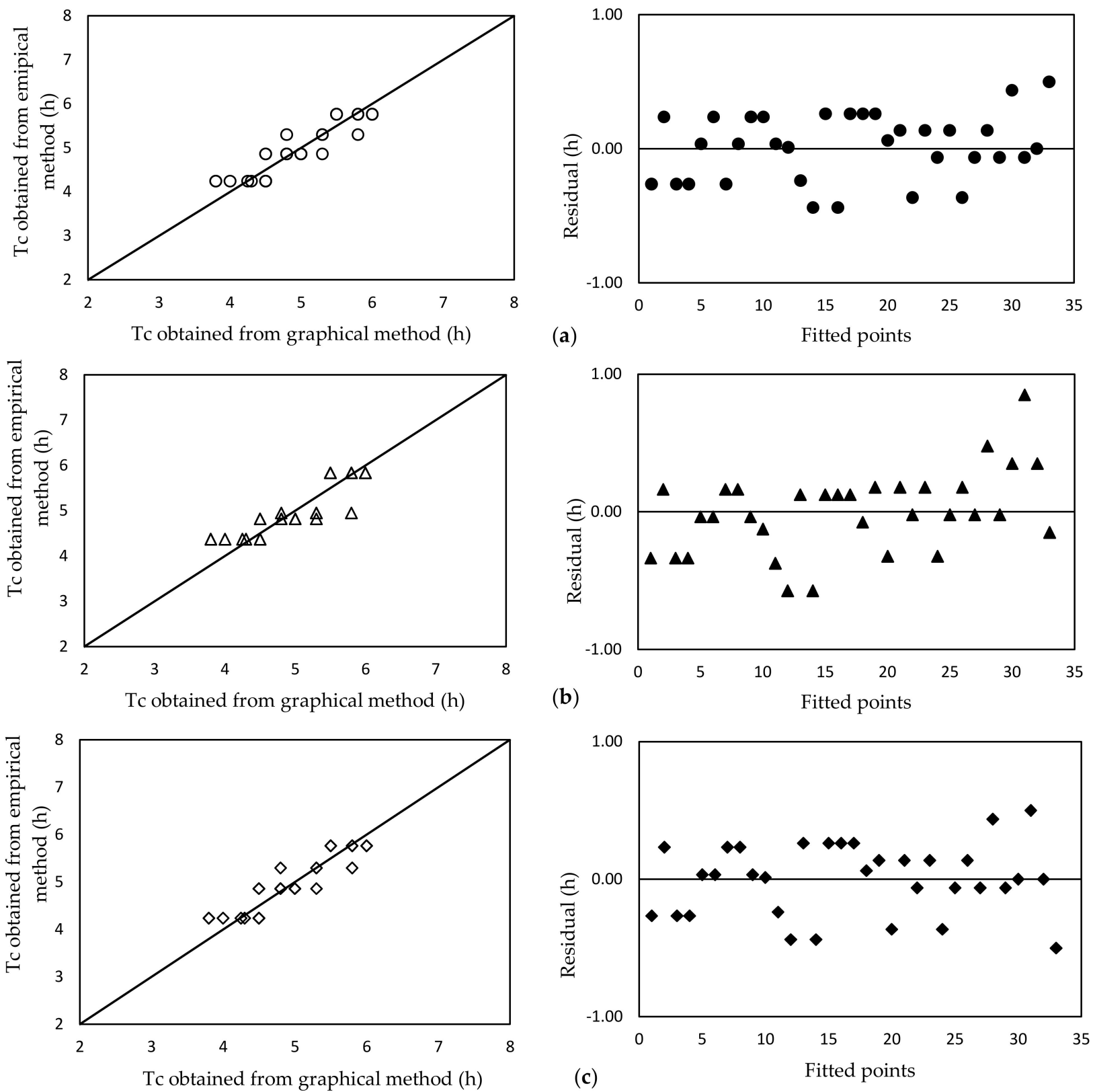

Figure 6. Tc Estimated by the modified empirical equations versus $\mathrm{T}_{\mathrm{C}}$ calculated by the graphical method and corresponding residual distribution: (a) modified Williams; (b) modified Pilgrim and Mac Dermott; (c) modified Arizona DOT.

\subsection{Cross Validation for Overfitting}

The leave-one-out cross validation was applied using 33 data parameters to evaluate the efficiency of the model. The mean square error and the variation of coefficient of correlation (predicted $\mathrm{R}$ ) resulted from cross validation process (Table 10). The results indicate the predicted error (shown in Table 10) is not substantially higher than the model error (shown in Table 8). Furthermore, using the process of cross validation, comparing the coefficient of correlation of the model and the range of predicted $\mathrm{R}$ shows there is not a large discrepancy between the two values. 
Table 7. Values of statistical measures and the ranking of methods.

\begin{tabular}{|c|c|c|c|c|c|}
\hline Method & MAPE & RMSE & SE & $\mathbf{R}$ & $\begin{array}{c}\text { Sum of } \\
\text { Rankings }\end{array}$ \\
\hline Bransby Williams & 135.49 & 7.64 & 245.60 & 0.831 & \multirow{2}{*}{49} \\
\hline Rank & 12 & 12 & 12 & 13 & \\
\hline Kirpich & 67.08 & 3.36 & -117.11 & 0.915 & \multirow[b]{2}{*}{30} \\
\hline Rank & 10 & 9 & 10 & 1 & \\
\hline Chow & 34.22 & 1.86 & 44.80 & 0.840 & \multirow{2}{*}{27} \\
\hline Rank & 6 & 6 & 6 & 9 & \\
\hline California Culverts Practice & 24.99 & 1.45 & -26.31 & 0.826 & \multirow{2}{*}{28} \\
\hline Rank & 5 & 5 & 4 & 14 & \\
\hline Arizona DOT & 24.37 & 1.32 & 22.72 & 0.874 & \multirow{2}{*}{16} \\
\hline Rank & 4 & 3 & 3 & 6 & \\
\hline Johnstone-Cross & 59.02 & 3.37 & 106.92 & 0.834 & \multirow[b]{2}{*}{38} \\
\hline Rank & 9 & 10 & 9 & 10 & \\
\hline Temez & 104.75 & 5.91 & 189.96 & 0.852 & \multirow[b]{2}{*}{40} \\
\hline Rank & 11 & 11 & 11 & 7 & \\
\hline Haktanir and Sezen & 205.74 & 10.93 & 367.25 & 0.832 & \multirow{2}{*}{50} \\
\hline Rank & 13 & 13 & 13 & 11 & \\
\hline Giandotti & 19.35 & 1.33 & -8.11 & 0.678 & \multirow{2}{*}{22} \\
\hline Rank & 2 & 4 & 1 & 15 & \\
\hline Ventura & 234.70 & 13.87 & 432.53 & 0.901 & \multirow{2}{*}{45} \\
\hline Rank & 14 & 14 & 14 & 3 & \\
\hline Pilgrim and Mac Dermott & 21.85 & 1.31 & 39.53 & 0.885 & \multirow{2}{*}{15} \\
\hline Rank & 3 & 2 & 5 & 5 & \\
\hline Pasini & 277.60 & 16.27 & 510.42 & 0.891 & \multirow{2}{*}{49} \\
\hline Rank & 15 & 15 & 15 & 4 & \\
\hline Williams & 16.92 & 0.97 & -8.21 & 0.831 & \multirow[b]{2}{*}{16} \\
\hline Rank & 1 & 1 & 2 & 12 & \\
\hline Dooge & 41.25 & 2.55 & 76.40 & 0.913 & \multirow[b]{2}{*}{24} \\
\hline Rank & 7 & 8 & 7 & 2 & \\
\hline Corps of Engineers & 45.66 & 2.29 & -79.06 & 0.852 & \multirow[b]{2}{*}{31} \\
\hline Rank & 8 & 7 & 8 & 8 & \\
\hline
\end{tabular}

Table 8. Modified equations of top three empirical methods for estimating Tc in the sub-watersheds of central parts of Hormozgan province.

\begin{tabular}{|c|c|c|c|c|c|}
\hline Empirical Method & Original Equation & Modified Equation & $\begin{array}{l}\text { Coefficient of } \\
\text { Correlation }\end{array}$ & $\begin{array}{l}\text { Mean Square } \\
\text { Error (MSE) }\end{array}$ & $\begin{array}{l}\text { Sum of } \\
\text { Residuals }\end{array}$ \\
\hline Williams & $\mathrm{T}_{\mathrm{C}}=0.272 \mathrm{~A}^{0.4} \frac{\mathrm{L}}{\mathrm{D}} \mathrm{S}_{\mathrm{C}}-0.2$ & $\mathrm{~T}_{\mathrm{C}}=1.51 \mathrm{~A}^{0.19}\left(\frac{\mathrm{L}}{\mathrm{D}}\right)^{-0.16} \mathrm{~S}_{\mathrm{c}}{ }^{-0.07}$ & 0.918 & 0.06 & $-7.1 \times 10^{-15}$ \\
\hline $\begin{array}{l}\text { Pilgrim and Mac } \\
\text { Dermott }\end{array}$ & $\mathrm{T}_{\mathrm{C}}=0.76 \mathrm{~A}^{0.38}$ & $\mathrm{~T}_{\mathrm{C}}=1.425 \mathrm{~A}^{0.23}$ & 0.885 & 0.09 & $-1.8 \times 10^{-2}$ \\
\hline Arizona DOT & $\begin{array}{l}\mathrm{T}_{\mathrm{C}}= \\
0.05508471 \mathrm{~A}^{0.1}\left(\mathrm{LL}_{\mathrm{ca}}\right)^{0.25} \mathrm{~S}_{\mathrm{c}}{ }^{-0.2}\end{array}$ & $\begin{array}{l}\mathrm{T}_{\mathrm{C}}= \\
1.22423 \mathrm{~A}^{0.27}\left(\mathrm{LL}_{\mathrm{ca}}\right)^{-0.07} \mathrm{~S}_{\mathrm{c}}{ }^{-0.08}\end{array}$ & 0.915 & 0.06 & $-3.1 \times 10^{-10}$ \\
\hline
\end{tabular}


Table 9. Tc achieved by the modified top three empirical methods and their relative difference with mean Tc calculated by graphical method.

\begin{tabular}{|c|c|c|c|c|}
\hline Sub-Watershed & $\begin{array}{l}\text { Mean Tc Estimated by } \\
\text { Graphical Method (h) }\end{array}$ & $\begin{array}{l}\text { Modified Empirical } \\
\text { Method }\end{array}$ & $\begin{array}{l}\text { Tc Estimated by } \\
\text { Modified Equation } \\
\text { (h) }\end{array}$ & Difference \% \\
\hline Shaghrud & 5.8 & \multirow{4}{*}{ Modified Williams } & 5.76 & -0.7 \\
\hline Sikhoran & 4.2 & & 4.24 & 0.9 \\
\hline Salubalm & 4.9 & & 4.86 & -0.8 \\
\hline Chahchakur & 5.3 & & 5.30 & 0 \\
\hline Shaghrud & 5.8 & \multirow{4}{*}{$\begin{array}{l}\text { Modified Pilgrim and } \\
\text { Mac Dermott }\end{array}$} & 5.84 & 0.7 \\
\hline Sikhoran & 4.2 & & 4.38 & 4.2 \\
\hline Salubalm & 4.9 & & 4.82 & -1.6 \\
\hline Chahchakur & 5.3 & & 4.95 & -6.6 \\
\hline Shaghrud & 5.8 & \multirow{4}{*}{ Modified Arizona DOT } & 5.77 & -0.5 \\
\hline Sikhoran & 4.2 & & 4.24 & 0.9 \\
\hline Salubalm & 4.9 & & 4.86 & -0.8 \\
\hline Chahchakur & 5.3 & & 5.30 & 0 \\
\hline
\end{tabular}

Table 10. The results of cross validation.

\begin{tabular}{ccc}
\hline Modified Methods & $\begin{array}{c}\text { Variation of Coefficient of } \\
\text { Correlation (Predicted R) }\end{array}$ & Mean Square Error (Predicted MSE) \\
\hline Modified Williams & $0.904-0.925$ & 0.09 \\
\hline Modified Pilgrim and Mac Dermott & $0.871-0.912$ & 0.10 \\
\hline Modified Arizona DOT & $0.910-0.928$ & 0.09 \\
\hline
\end{tabular}

\section{Limitations}

Collecting data that covers a wide range of conditions and a long-time span is crucial in developing or modifying empirical models. In arid regions, the most important limitation is the lack of data. In this study, there were only four gauged sub-watersheds available. In each studied sub-watershed, there was one rainfall station and in overall there were 33 recorded rainfall-runoff events. The lack of complete rainfall and runoff gauge networks makes hydrologic studies in arid regions a hard task. In this study, the empirical models were evaluated and modified with these limitations. Because there was not a wide range of data in the analyses, the findings of this study may not give the best accuracy. However, the results are worthwhile for the local design engineers that use empirical methods without evaluation and are only based on expert judgments. In order to create a more detailed analysis of the behavior of sub-watersheds during rainfalls, the existence of a complete dataset is necessary. With the completion of data, it is suggested that the results of this study be updated.

In this study several commonly used statistical measures were applied in the ranking based strategy to select top three methods for the study region. The selection of measures used in this study for other regions could lead to different top three methods. Thus, the top three methods proposed in this paper are valid only for the study area and selecting the best performing method(s) in the other regions by the proposed approach needs a particular regional evaluation for those regions.

\section{Conclusions}

The importance of Tc in hydrological designs has led to the development of a variety of empirical methods for estimating this parameter in ungauged sub-watersheds. Because each method was developed for a particular geographic region, care must be taken in the selection of an appropriate method for determining Tc in other regions. This study focuses on the evaluation and modification of empirical methods in arid regions to gain 
proper estimations of Tc in ungauged sub-watersheds. Throughout this paper, the graphical method, based on the analysis of hyetographs and hydrographs of events in gauged subwatersheds, was used as a reference method for calculating Tc. Results from the graphical method were compared to 15 empirical methods. Several statistical measures were used to evaluate and rank each empirical method, and, from that, the best performing methods were identified. To minimize the bias and improve the estimations, the best empirical methods were modified for specific use in ungauged sub-watersheds of the study area, the Hormozgan province, Iran. According to the results of the study, three methods of (1) Pilgrim and Mac Dermott, (2) Williams, and (3) Arizona DOT were the most appropriate empirical methods for estimating Tc in this region. The modification of these formulas significantly improved their estimations. This research indicated that using the modified Arizona DOT method and modified Williams method can lead to the best estimation of Tc, as they can estimate Tc with an error lower than $1 \%$.

According to the findings of this study and the recent findings of other studies about the importance of applying rainfall-runoff data in estimating the Tc, it is recommended that future studies focus on developing new empirical models using graphical methods on the regional scale for geographically different areas.

Author Contributions: Conceptualization, A.Z.; methodology, A.Z., R.B. and A.L.; software, A.Z.; validation, A.Z., R.B. and A.L.; formal analysis, A.Z., R.B. and A.L.; investigation, A.Z., R.B. and A.L.; resources, A.Z., R.B. and A.L.; data curation, A.Z., R.B. and A.L.; writing-original draft preparation, A.Z., R.B. and A.L.; writing-review and editing, A.Z., R.B. and A.L.; visualization, A.Z., R.B. and A.L.; supervision, A.Z., R.B. and A.L.; project administration, A.Z., R.B. and A.L.; funding acquisition, A.Z., R.B. and A.L. All authors have read and agreed to the published version of the manuscript.

Funding: This research received no external funding.

Institutional Review Board Statement: Not applicable.

Informed Consent Statement: Not applicable.

Data Availability Statement: Not applicable.

Acknowledgments: The authors would like to thank Mehrdad Mohseni for providing the GIS maps, and the Hormozgan Regional Water Authority Company and Zayandab Consulting Engineers for providing the rainfall and runoff data.

Conflicts of Interest: The authors declare no conflict of interest.

\section{References}

1. Schick, A.P. Hydrologic aspects of floods in extreme arid environments. Flood Geomorphol. 1988, 189-203.

2. Zeng, X.; Zeng, X.; Barlage, M. Growing temperate shrubs over arid and semiarid regions in the Community Land Model-Dynamic Global Vegetation Model. Glob. Biogeochem. Cycles 2008, 22, 1-14. [CrossRef]

3. Alinezhad, A.; Gohari, A.; Eslamian, S.; Baghbani, R. Uncertainty Analysis in Climate Change Projection Using Bayesian Approach. In Proceedings of the World Environmental and Water Resources Congress, Henderson, NV, USA, 17-21 May 2020; American Society of Civil Engineers: Henderson, NV, USA, 2020; pp. 167-174. [CrossRef]

4. Pavlovic, S.B.; Moglen, G.E. Discretization Issues in Travel Time Calculation. J. Hydrol. Eng. 2008, 13, 71-79. [CrossRef]

5. Bondelid, T.R.; McCuen, R.H.; Jackson, T.J. Sensitivity of SCS Models to Curve Number Variation1. JAWRA J. Am. Water Resour. Assoc. 1982, 18, 111-116. [CrossRef]

6. Higgins, R.W.; Douglas, A.; Hahmann, A.; Berberry, E.H.; Gutzler, D.; Shuttleworth, J.; Stensrud, D.; Amador, J.; Carbone, R.; Cortez, M.; et al. Progress in Pan American CLIVAR research: The North American monsoon system. Atmosfera 2003, $16,29-65$.

7. Azizian, A. Uncertainty Analysis of Time of Concentration Equations based on First-Order-Analysis (FOA) Method. Am. J. Eng. Appl. Sci. 2018, 11, 327-341. [CrossRef]

8. Efstratiadis, A.; Koussis, A.D.; Koutsoyiannis, D.; Mamassis, N. Flood design recipes vs. reality: Can predictions for ungauged basins be trusted? Nat. Hazards Earth Syst. Sci. 2014, 14, 1417-1428. [CrossRef]

9. Salimi, E.T.; Nohegar, A.; Malekian, A.; Hoseini, M.; Holisaz, A. Estimating time of concentration in large watersheds. Paddy Water Environ. 2017, 15, 123-132. [CrossRef]

10. González-Álvarez, Á.; Molina-Pérez, J.; Meza-Zúñiga, B.; Viloria-Marimón, O.M.; Tesfagiorgis, K.; Mouthón-Bello, J.A. Assessing the performance of different time of concentration equations in urban ungauged watersheds: Case study of Cartagena de Indias, Colombia. Hydrology 2020, 7, 47. [CrossRef] 
11. Sharifi, S.; Hosseini, S.M. Methodology for Identifying the Best Equations for Estimating the Time of Concentration of Watersheds in a Particular Region. J. Irrig. Drain. Eng. 2011, 137, 712-719. [CrossRef]

12. Perdikaris, J.; Gharabaghi, B.; Rudra, R. Reference Time of Concentration Estimation for Ungauged Catchments. Earth Sci. Res. 2018, 7, 58. [CrossRef]

13. McCuen, R.H. Uncertainty Analyses of Watershed Time Parameters. J. Hydrol. Eng. 2009, 14, 490-498. [CrossRef]

14. Beven, K. A history of the concept of time of concentration. Hydrol. Earth Syst. Sci. 2020, 24, 2655-2670. [CrossRef]

15. McCuen, R.H.; Wong, S.L.; Rawls, W.J. Estimating Urban Time of Concentration. J. Hydraul. Eng. 1984, 110, 887-904. [CrossRef]

16. Kaufmann de Almeida, I.; Kaufmann Almeida, A.; Garcia Gabas, S.; Alves Sobrinho, T. Performance of methods for estimating the time of concentration in a watershed of a tropical region. Hydrol. Sci. J. 2017, 62, 2406-2414. [CrossRef]

17. Mudashiru, R.B.; Abustan, I.; Baharudin, F. Methods of Estimating Time of Concentration: A Case Study of Urban Catchment of Sungai Kerayong, Kuala Lumpur. Lect. Notes Civ. Eng. 2020, 53, 119-161. [CrossRef]

18. Grimaldi, S.; Petroselli, A.; Tauro, F.; Porfiri, M. Time of concentration: A paradox in modern hydrology. Hydrol. Sci. J. 2012, 57, 217-228. [CrossRef]

19. Dunne, T.; Black, R.D. Partial Area Contributions to Storm Runoff in a Small New England Watershed. Water Resour. Res. 1970, 6, 1296-1311. [CrossRef]

20. Lim, T.C. Predictors of urban variable source area: A cross-sectional analysis of urbanized catchments in the United States. Hydrol. Process. 2016, 30, 4799-4814. [CrossRef]

21. Kjeldsen, T.R.; Kim, H.; Jang, C.-H.; Lee, H. Evidence and Implications of Nonlinear Flood Response in a Small Mountainous Watershed. J. Hydrol. Eng. 2016, 21, 04016024. [CrossRef]

22. Delleur, R.A.; Rao, R.A. Instantaneous unit hydrographs, peak discharges and time lags in urban basins. Hydrol. Sci. Bull. 1974, 19, 185-198. [CrossRef]

23. Sharma, K.D.; Murthy, J.S.R. A practical approach to rainfall-runoff modelling in arid zone drainage basins. Hydrol. Sci. J. 1998, 43, 331-348. [CrossRef]

24. Lange, J.; Leibundgut, C. Non-calibrated arid zone rainfall-runoff modelling. IAHS-AISH Publ. 2000, 45-52.

25. Kirpich, Z.P. Time of concentration of small agricultural watersheds. Civ. Eng 1940, 10, 362.

26. Singh, V.P. Hydrologic Systems: Rainfall-Runoff Modeling; Hydrologic Systems; Prentice Hall: Englewood Cliffs, NJ, USA, 1988; ISBN 9780134480510.

27. Guermond, Y. The Modeling Process in Geography: From Determinism to Complexity, ISTE, 1st ed.; Wiley: Hoboken, NJ, USA, 2013; ISBN 9781118622575.

28. Li, M.H.; Chibber, P. Overland flow time of concentration on very flat terrains. Transp. Res. Rec. 2008, 133-140. [CrossRef]

29. Marek, M.A. Hydraulic Design Manual; Texas Department of Transportation (TxDOT): Austin, TX, USA, 2011.

30. Pilgrim, D.H.; Chapman, T.G.; Doran, D.G. Problems of rainfall-runoff modelling in arid and semiarid regions. Hydrol. Sci. J. 1988, 33, 379-400. [CrossRef]

31. Chow, V.T.; Maidment, D.R.; Mays, L.W. Applied Hydrology McGraw-Hill Book Company; MacGraw-Hill. Inc: New York, NY, USA, 1988.

32. Fang, X.; Prakash, K. Revisit of NRCS unit hydrograph procedures. In Proceedings of the ASCE Texas Section Spring Meet, Austin, TX, USA, 2005; pp. 1-12. Available online: https:/ / www.researchgate.net/publication/253038310_Revisit_of_NRCS_ Unit_Hydrograph_Procedures (accessed on 17 September 2021).

33. Fang, X.; Thompson, D.B.; Cleveland, T.G.; Pradhan, P.; Malla, R. Time of Concentration Estimated Using Watershed Parameters Determined by Automated and Manual Methods. J. Irrig. Drain. Eng. 2008, 134, 202-211. [CrossRef]

34. Mateo Lázaro, J.; Sánchez Navarro, J.Á.; García Gil, A.; Edo Romero, V. Sensitivity analysis of main variables present in flash flood processes. Application in two Spanish catchments: Arás and Aguilón. Environ. Earth Sci. 2014, 71, 2925-2939. [CrossRef]

35. Hadadin, N. Evaluation of several techniques for estimating stormwater runoff in arid watersheds. Environ. Earth Sci. 2013, 69, 1773-1782. [CrossRef]

36. Chin, D.A. On relationship between curve numbers and phi indices. Water Sci. Eng. 2018, 11, 187-195. [CrossRef]

37. McCuen, R.H. Hydrologic Analysis and Design, 4th ed.; Pearson: Upper Saddle River, NJ, USA; University of Maryland: College Park, MD, USA, 2017.

38. Gupta, R.S. Hydrology and Hydraulic Systems, 4th ed.; Waveland Press: Long Grove, IL, USA, 2016 ; ISBN 1478634219.

39. Singh, V.P. Elementary Hydrology; Prentice Hall: Englewood Cliffs, NJ, USA, 1992.

40. American Society of Civil Engineers; Task Committee on Hydrology Handbook. Hydrology Handbook; ASCE: New York, NY, USA, 1996; ISBN 9780784470145.

41. Linsley, R.K. Discussion of "Correlation of rainfall intensity and topography in Northern California. Eos, Trans. Am. Geophys. Union 1958, 39, 970-972. [CrossRef]

42. Lopes, S.; Fragoso, M.; Lopes, A. Heavy rainfall events and mass movements in the funchal area (Madeira, Portugal): Spatial analysis and susceptibility assessment. Atmosphere 2020, 11, 104. [CrossRef]

43. Legates, D.R.; McCabe Jr, G.J. Evaluating the use of "goodness-of-fit" measures in hydrologic and hydroclimatic model validation. Water Resour. Res. 1999, 35, 233-241. [CrossRef]

44. Datafit Data Curve Fitting (Nonlinear Regression) and Data Plotting Software. 2009. 
45. Lever, J.; Krzywinski, M.; Altman, N. Points of significance: Model selection and overfitting. Nat. Methods 2016, 13, 703-705. [CrossRef]

46. Wong, T.S. Assessment of Time of Concentration Formulas for Overland Flow. J. Irrig. Drain. Eng. 2005, 131, 383-387. [CrossRef]

47. Sehler, R.; Li, J.; Reager, J.; Ye, H. Investigating Relationship Between Soil Moisture and Precipitation Globally Using Remote Sensing Observations. J. Contemp. Water Res. Educ. 2019, 168, 106-118. [CrossRef]

48. Luo, W.; Harlin, J.M. A theoretical travel time based on watershed hypsometry. J. Am. Water Resour. Assoc. 2003, 39, 785-792. [CrossRef]

49. Tucker, G.E.; Bras, R.L. Hillslope processes, drainage density, and landscape morphology. Water Resour. Res. 1998, 34, $2751-2764$. [CrossRef]

50. Pallard, B.; Castellarin, A.; Montanari, A. A look at the links between drainage density and flood statistics. Hydrol. Earth Syst. Sci. Discuss. 2008, 5, 2899-2926. [CrossRef]

51. ASCE Task Committee on Definition of Criteria for Evaluation of Watershed Models of the Watershed Management Committee. Criteria for evaluation of watershed models. J. Irrig. Drain. Eng. 1993, 119, 429-442. [CrossRef]

52. Vijai, G.H.; Soroosh, S.; Ogou, Y.P. Status of Automatic Calibration for Hydrologic Models: Comparison with Multilevel Expert Calibration. J. Hydrol. Eng. 1999, 4, 135-143. [CrossRef]

53. Willmott, C.J.; Ackleson, S.G.; Davis, R.E.; Feddema, J.J.; Klink, K.M.; Legates, D.R.; O'donnell, J.; Rowe, C.M. Statistics for the evaluation and comparison of models. J. Geophys. Res. Ocean. 1985, 90, 8995-9005. [CrossRef]

54. Zahraei, A.; Eslamian, S.; Rizi, A.S.; Azam, N.; Soltani, M.; Mousavi, M.; Pazdar, S.; Ostad-Ali-Askari, K. Mapping of Temperature Trend Slope in Iran's Zayanderud River Basin: A Comparison of Interpolation Methods. Am. J. Eng. Appl. Sci. 2019, 12, 247-258. [CrossRef]

55. Singh, J.; Knapp, H.V.; Arnold, J.G.; Demissie, M. Hydrological modeling of the Iroquois River watershed using HSPF and SWAT J. Am. Water Resour. Assoc. 2005, 41, 343-360. [CrossRef]

56. Moriasi, D.N.; Arnold, J.G.; Van Liew, M.W.; Bingner, R.L.; Harmel, R.D.; Veith, T.L. Model evaluation guidelines for systematic quantification of accuracy in watershed simulations. Trans. ASABE 2007, 50, 885-900. [CrossRef]

57. KC, M.; Fang, X.; Yi, Y.-J.; Li, M.-H.; Thompson, D.B.; Cleveland, T.G. Improved Time of Concentration Estimation on Overland Flow Surfaces Including Low-Sloped Planes. J. Hydrol. Eng. 2014, 19, 495-508. [CrossRef] 